\title{
Genetic and environmental factors that affect tick infestation in Nelore $x$ Angus crossbreed cattle
}

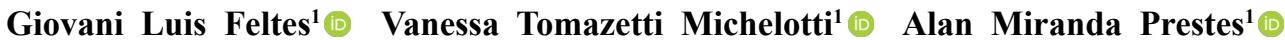 \\ Paulo Roberto Nogara Rorato ${ }^{1}$ (i) Fernanda Cristina Breda Mello ${ }^{1^{*}}$ (i) \\ Mauricio Morgado Oliveira ${ }^{1}\left[\right.$ Vanerlei Mozaquatro Roso $^{2}$ (1)
}

'Departamento de Zootecnia, Universidade Federal de Santa Maria (UFSM), 97105-900, Santa Maria, RS, Brasil. E-mail: fernandabreda@gmail.com. "Corresponding author.

${ }^{2}$ GenSys Consultores Associados S/S Ltda, Porto Alegre, RS, Brasil.

ABSTRACT: This study evaluated the effects of seasons and latitude on tick counting and determined the best model to estimate genetic parameters for tick count and hair coat. Records of animals naturally exposed to ticks on farms in several Brazilian states and in Paraguay were used. The ANOVA was used to verify the effects of seasons and latitude on the tick count trait. Spring was the season with the highest average, followed by summer and autumn, which showed no differences between them. The winter presented the lowest average values. Latitude $-11^{\circ}$ had the highest mean value followed by latitude $-18^{\circ}$. The Bayesian approach was used to evaluate tick count and hair coat and to identify a suitable model for estimating genetic parameters for use in genetic evaluations. The data were analyzed using an animal model with four different specifications for "fixed" purposes. The inference was based on a Markov chain Monte Carlo (MCMC). The criteria for selection of the Bayesian model indicated that the M1 model, which considered the breed composition in the contemporary group, was superior to the other models, both for tick count and hair coat. Heritability estimates for tick count and hair coat obtained using the M1 model were 0.14 and 0.22 , respectively. The rank correlations between the models for tick count and hair coat were estimated and reordering was verified for tick count. The estimated genetic correlation between tick count and hair coat traits was negative (-0.12). These findings suggest that different genes regulate tick count and hair coat.

Key words: fixed effects, hair coat, heritability, genetic correlation, rank correlation.

Fatores genéticos e ambientais que afetam a infestação de carrapatos em bovinos cruzados Nelore $x$ Angus

\begin{abstract}
RESUMO: Os objetivos foram avaliar os efeitos das estações e latitude na contagem de carrapatos e determinar o melhor modelo para estimar parâmetros genéticos para contagem de carrapatos e pelame. Foram utilizados registros de animais expostos naturalmente a carrapatos em fazendas em vários estados brasileiros e no Paraguai. A ANOVA foi utilizada para verificar os efeitos das estaçóes e da latitude na característica de contagem de carrapatos. A primavera foi a estação com a maior média, seguida pelo verão e outono, que não mostraram diferenças entre eles. O inverno apresentou os menores valores médios. A latitude $-11^{\circ}$ teve o maior valor médio seguido pela latitude -1 $8^{\circ}$. A abordagem bayesiana foi usada para avaliar a contagem de carrapatos e o pelame e identificar o modelo adequado para estimar parâmetros genéticos e para uso em avaliações genéticas. Os dados foram analisados usando um modelo animal com quatro especificações diferentes para efeitos "fixos". A inferência foi baseada em uma cadeia de Markov Monte Carlo (MCMC). Os critérios de seleção do modelo bayesiano indicaram que o modelo M1, que considerou a composição racial no grupo contemporâneo, foi superior aos demais modelos, tanto na contagem de carrapatos e para pelame. As estimativas de herdabilidade para contagem de carrapatos e pelame obtidas usando o modelo M1 foram de 0,14 e 0,22, respectivamente. As correlações de ranking entre os modelos para a contagem de carrapatos e pelame foram estimadas e a reordenação foi verificada para a contagem de carrapatos. A correlação genética estimada entre a contagem de carrapatos e pelame foi negativa (-0,12). Esses achados sugerem que genes diferentes regulam a contagem de carrapatos e pelame.

Palavras-chave: efeitos fixos, Pelame, herdabilidade, correlação genética, correlação de ranking.
\end{abstract}

\section{INTRODUCTION}

Brazil is the largest beef exporter and producer in the world. For efficient commercial exploitation, animals with productive potential and adapted to the environment are needed. In this context, the resistance to the tick Rhipicephalus (Boophilus) microplus is among the traits of economic importance for genetic evaluation in beef cattle. Ticks are among the most relevant vectors of 
diseases affecting livestock, pets and humans because of their ability to host and transmit disease-causing organisms (GASPARIN et al., 2007). These include pathogenic protozoa, rickettsia, spirochaetes and viruses (JONGEJAN \& UILENBERG, 2004).

It is responsible for direct and indirect causes of economic loss, and chemical control is costly (JONSSON, 2006). The tick causes a losses are more likely to be in the vicinity of US\$22-30 billion dollars in livestock yearly, these economic losses were estimated considering the total number of animals at risk and the negative effects of parasitism on cattle productivity, based on known yield losses in untreated animals (LEW-TABOR \& RODRIGUEZ VALLE, 2016).

Environmental and genetic factors influence the number of $R$. microplus ticks on hosts. In general, Bos taurus cattle are more susceptible to ectoparasites than Bos indicus cattle in tropical environments, and much of this difference is under genetic control (GASPARIN et al., 2007). However, under favorable environmental conditions, Bos Taurus animals are more advantageous in terms of productive traits. Thus, the use of crossbreed animals combining the adaptability of Zebu breeds and the productivity of Taurine breeds seems to be an excellent strategy for cattle production in tropical countries (AYRES et al., 2013).

In his review BURROW et al. (2019) identified several animal and environmental factors that affect resistance of cattle to ticks, and, hence, must be considered in the design of cattle-resource population(s) established to measure cattle tick resistance, such as: sex, age, season, coat type, treatment for other ecto and endo parasites and stressful factors (high temperatures and humidity, nutritional deficit). The efficiency of production systems is reduced by all these factors, therefore, they need to be studied, so that it can become possible to use new control methodologies for this type of mite, which has a major impact on the beef cattle production system in tropical and subtropical countries (FRAGA et al., 2003; MENDES et al., 2011).

The fact that part of the tick's life cycle occurs in the environment makes it important to study environmental factors such as season and latitude (ANDRADE et al., 1998; CARDOSO et al., 2000). According to PENNA (1989), environmental effects can influence the accuracy of tick resistance evaluations, thus leading to reduced confiability in genetic value predict.

The growing development of resistance against acaricides among tick populations and the possibility of environmental contamination caused by chemical treatments have stimulated many researchers to investigate the genetic resistance of cattle to the tick $R$. microplus as alternative control method (LA FUENTE, et al., 2007).

Variation in natural resistance is a consequence of the animals' ability to respond immunologically to tick infestation. Different estimates of heritability for the tick count in cattle are reported in the literature, ranging from 0.12 (AYRES et al., 2014) to 0.54 (OTTO et al., 2018).

Tick counting can also be associated with animal hair characteristics (VERÍSSIMO et al., 2019), in addition to being related to thermoregulation and adaptation to the environment (REIMANN et al., 2018), which are fundamental for animal production. According to FRAGA et al. (2003), the hair thickness of the animal is an important factor in tick infestation, and the greater the hair thickness, the greater the infestation is; animals with short and straight hair coat present lower caloric stress rates and, consequently, higher resistance.

The objectives of this study were to ascertain the influence of seasons and latitude on tick infestation and to determine the best model for estimating genetic parameters for tick counts and hair coat.

\section{MATERIALS AND METHODS}

Records of tick count and hair coat in Brangus cattle breeds used in this study were derived by Natura Genética Sul Americana Breeding Program and Gensys Associated Consultants. This database is built by producers from different country regions, which have, in their production system, Nelore x Angus crossbred cattle more adapted to the environment. Thus, the breed composition ranged (pure Angus to $3 / 4$ Nelore-Angus) according to their breeding region.

All animals participating in the genetic evaluation program were reared on pastures and evaluated by counting adult tick females teleogens $(\geq 4.5 \mathrm{~mm}$ ) attached in the area between the inner sides of the hind limbs to evaluate individual resistance to this parasite. Because tick counts were not normally distributed, a log-transformation was used such that LTC $=\log _{10}(n+$ $1.001)$, where $n$ is the number of ticks, which was used as the response variable (AYRES et al., 2013). To ensure the normality of the residuals from the fitted models, tests of kurtosis and skew ness test were performed.

The data file for univariate analysis was composed by 5,851 animals sired by 295 sires and 5,247 dams between 2002 and 2012 and aged from 369 to 696 days old from twenty-six herds located in the Brazilian states of Goiás, Minas Gerais, Mato Grosso do Sul, Paraná, Rio Grande do Sul, São 
Paulo and Tocantins and in Paraguay, totaling 13,989 records.

The hair coat was evaluated at yearling, receiving score 1 the animals with extremely short and sleek hair and 3 those with very woolly hair. The seasons in which tick counts were taken were defined as: summer (from January to March), autumn (from April to June), winter (from July to September), and spring (October to December) and at the following latitudes: $-11,-18,-22,-23,-24,-26,-29$.

In order to ascertain the effects of season and latitude on tick counts, univariate analysis of variance was performed, using the following model: $y_{i j}=\mu+\tau_{i}+\varepsilon_{i j}$, where $y_{i j}$ : is the tick counts record on the $j^{\text {th }}$ animal in the $i^{\text {th }}$ season or latitude; $\mu=$ the overall mean; $\tau_{i}=$ the $i^{\text {th }}$ fixed effect of season or latitude; and $\varepsilon_{i j}=$ random residual error. Significances were tested at $\mathrm{P}<$ 0.05 level, and Tukey's multiple range test was used to compare means among treatments, through the SAS 9.3 software (SAS, 2013).

The genetic analysis was performed using a linear animal model for tick counts and a threshold animal model for hair coat. Considering all animals, the model can be written in matrix form as:

$y=X \beta+Z a+e$ vhere $y$ is vector of observations for tick count or hair coat; $X$ is incidence matrix associated with fixed effects; $\beta$ is vector of solutions for fixed effects; $\mathrm{Z}$ is incidence matrix for direct additive effect; $a$ is vector of the direct additive genetic effect; $e$ is vector of residuals. The assumptions used for model were: $E(y)=X b ; E(a)=0 ; E(e)=0 ; \operatorname{var}(\mathrm{a})=A \sigma_{a}^{2}$; $\operatorname{var}(\mathrm{e})=I_{N} \sigma_{e}^{2}$ where $A$ where is numerator of there relationship matrix; $\sigma_{a}^{2}$ is component of direct additive genetic variance; $\sigma_{e}^{2}$ is component of residual variance; $N$ is number of observations; and $I$ is identity matrix of order $N$.

We evaluated four models differing in the composition of the contemporary groups: M1 contemporary group (CG) formed by the combination of the effects of year and season of birth, sex, farm, breed composition, management group, latitude and date of counting; M2 - the breed composition was considered in classes outside the CG; M3 - the CG was equal to M2, but the breed composition was defined as a covariable; M4 - considering two CGs: CG1 - considering the year and season of birth, sex, farm, management group and date of counting; and CG2 - considering only latitude and breed composition. In all the models, linear effect of animal age at recording was considered as covariable.

Records from sires with less than five offspring, contemporary groups with less than five animals and records outside \pm 3.5 standard deviation in relation to the mean tick count of the contemporary group were excluded. The number of observations, sires and contemporary groups for both traits are presented in table 1 .

Covariance components and genetic parameter were estimated using software BLUPF90 family (MISZTAL et al., 2015), which uses Bayesian inference based on a Markov Chain Monte Carlo (MCMC) chain of 110,000 cycles were considered with a interval of 10 samples and burn-in period of 10,000 samples. We evaluated the convergence criterion proposed by (GEWEKE, 1992). The software R

Table 1 - Tick count means and standard deviations according to the season and latitude.

\begin{tabular}{|c|c|c|}
\hline Season & Mean $^{*}$ (standard deviation) & Number of observations \\
\hline Spring & $0.62 \mathrm{a}(0.05)$ & 96 \\
\hline Autumn & $0.45 b(0.01)$ & 1,337 \\
\hline Summer & $0.43 b(0.00)$ & 4,037 \\
\hline Winter & $0.24 \mathrm{c}(0.02)$ & 381 \\
\hline Latitude & Mean* (standard deviation) & Number of observations \\
\hline$-11^{\circ}$ & $0.92 \mathrm{a}(0.01)$ & 703 \\
\hline$-18^{\circ}$ & $0.54 \mathrm{~b}(0.02)$ & 449 \\
\hline$-29^{\circ}$ & $0.42 \mathrm{c}(0.01)$ & 1,737 \\
\hline$-24^{\circ}$ & $0.39 \mathrm{c}(0.02)$ & 339 \\
\hline$-23^{\circ}$ & $0.30 \mathrm{~d}(0.02)$ & 439 \\
\hline$-22^{\circ}$ & $0.28 \mathrm{~d}(0.01)$ & 679 \\
\hline$-26^{\circ}$ & $0.28 \mathrm{~d}(0.01)$ & 1,505 \\
\hline
\end{tabular}

*means with the same letter were not statistically different. 
-version 3.4.1(R Core Team, 2017), with some routines of the package Bayesian Output Analysis (BOA) was used to calculated Geweke's statistic (SMITH, 2007).

For selection of an appropriate model were used the deviance information criterion - DIC and estimated number of effective parameters -pD (SPIEGELHALTER et al., 2002). Spearman rank correlations were calculated based on the estimated genetic values for M1, M2, M3 and M4 models for top $10 \%$ of sires for tick counting and hair coat.

\section{RESULTS AND DISCUSSION}

The animal average age was $554 \pm 44$ days, and the overall mean tick counts was equal to 5.79 with a standard deviation of 15.34, AYRES et al. (2014) reported an average of 11.28 and a standard deviation of 11.99 for the tick count in Hereford and Braford animals using the same counting methodology. Using another methodology for tick counting MOTA et al. (2016) reported an average of 35 and standard deviation of 42.4 for the number of ticks in animals of the Hereford and Braford breeds. These differences can be explained by the different breeds and also by the counting method.

The total observations by hair coat in each score: $1=63.33 \% ; 2=28.80 \%$ and the $3=7.88 \%$, score 1 is considered the best for animal production, that is, most animals present haircoat score ideal.

The Winter was the season that presented the lowest tick infestation (Table 1), which is characterized by lower rainfall and temperatures. Spring was the season that presented the highest infestation Tick needs specific weather conditions for their development (SCHLÖGL et al., 2020) especially temperature, humidity and intensity light hours.

The non-parasitic part of the tick's life during which they spend on the ground (maturation of eggs and larvae) is more dependent on climatic conditions than the parasitic phase (larva's, nymphs, adults, reproduction and engorged females), as they are adhered to the animal's body. As the light hours and temperature increase, tick activity increases. Therefore, a study by region should be done to determine which climatic conditions are favorable for free-living phases, for example, BRUM et al. (1987) in Pelotas-RS, ANDRADE et al. (1998) in São Carlos-SP and GUGLIELMONE \& NAVA (2013) in Argentina reported highest infestation in autumn; FRAGA et al. (2003) in São Paulo and Mato Grosso do Sul during summer.

The smallest infestations were observed in Latitudes $-22^{\circ},-23^{\circ}$ and $-26^{\circ}$, possibly due to higher concentration of animals $5 / 8$ Angus, $49.65 \%$ in -22 $\circ, 95.9 \%$ in $-23^{\circ}$ and $86.64 \%$ in $-26^{\circ}$, SILVA et al. (2007) observed that Nelore cattle are more resistant to ticks than do Angus $\times$ Nelore. The animals raised at latitude $-11^{\circ}$ showed greatest infestation, followed by latitude $-18^{\circ}$, suggesting that the closer the line to the equator, the greater the infestation. RODRÍGUEZMOLANO et al. (2020) related is widely distributed in tropical and subtropical regions between $32{ }^{\circ} \mathrm{N}$ and $35^{\circ} \mathrm{S}$ latitude, covering Central and South America, Africa and Oceania.

In genetic analysis, models were compared using the Deviance Information Criteria (DIC) and the effective number of parameters (pD), favored the M1 model for both traits (Table 2). The worst fit was obtained by the model M2 and M4 according to $\mathrm{pD}$ and DIC, respectively, for tick count and by M2 according to $\mathrm{pD}$ and DIC only for hair coat.

The best adjustment obtained by model M1 can be due the interaction of the breed composition with the other environmental effects. This means that the performance of the breed composition will be different for each combination of year and season of birth, sex, farm, management group, latitude and date of counting. Failure to consider this interaction results in a biased estimate of genetic parameters.

There is no consensus on the size of the group of animals and the common conditions needed to form the CG (SILVA et al., 2017). These criteria aim to maximize homogeneity within the $\mathrm{CG}$, resulting in a smaller number of animals per group. Therefore, the strategies used to define the $\mathrm{CG}$ may affect the prediction accuracy of the expected differences between progenies. The incorrect GCs formation leads to incorrect decision making, which in turn leads to the prediction of overestimated and underestimated genetic values, respectively, for animals favored in GCs and subject to less favorable conditions to express their genetic potential (COBUCI et al., 2006).

The residual variance was similar for all models $(\cong 0.12)$ for tick count (Table 3 ). Divergences were observed regarding for genetic 
Table 2 - Number of observations, number of sires and mean deviance, effective number of parameters ( $\left.\mathrm{p}_{\mathrm{D}}\right)$ and deviance information criterion (DIC) by models for tick count and hair coat.

\begin{tabular}{|c|c|c|c|c|c|}
\hline Model & Number of observations & Number of sires & Mean deviance & $\mathrm{pD}$ & DIC \\
\hline \multicolumn{6}{|c|}{---------------------------------------------------------------------------------Tick count---------------------------------------------------------------------- } \\
\hline M1 & 5,851 & 295 & 4,211 & 895 & 5,106 \\
\hline M2 & 6,506 & 323 & 4,110 & 1,596 & 5,706 \\
\hline M3 & 6,506 & 323 & 4,629 & 1,141 & 5,770 \\
\hline M4 & 6,506 & 323 & 4,827 & 976 & 5,803 \\
\hline \multicolumn{6}{|c|}{ 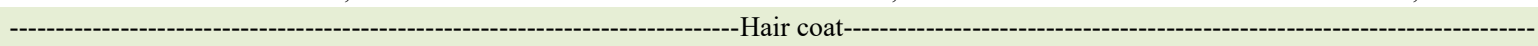 } \\
\hline M1 & 38,773 & 898 & 39,654 & 8,014 & 47,668 \\
\hline M2 & 40,629 & 919 & 39,818 & 9,966 & 49,784 \\
\hline M3 & 40,629 & 919 & 40,479 & 9,172 & 49,651 \\
\hline M4 & 40,629 & 919 & 41,374 & 8,268 & 49,642 \\
\hline
\end{tabular}

M1 = breed composition within the contemporary group; M2 = breed composition outside of the contemporary group; M3 = breed composition as covariable and M4 = two contemporary groups; the first comprised sex, management group, year and season of the count, and the second considered only the effects of latitude and breed composition.

variance, being the lowest for M1 and M4 (0.02), which resulted in lower heritabilities $(0.14)$ when compared to M2 (0.26) and M3 (0.18). Considering that M1 was indicated by the statistical criteria as the most appropriate, it seems that the wrong formation of contemporary groups leads to heritability overestimation and; consequently, to mistakes in the choice of animals and the expected genetic gain per generation.

In the case of M1 the genetic gain will be slow (Table 3); nevertheless, the gain by selection of the more resistant animals is cumulative and

Table 3 - Additive genetic $\left(\sigma_{a}^{2}\right)$, residual $\left(\sigma_{e}^{2}\right)$ and phenotypic variance $\left(\sigma_{p}^{2}\right)$ and Heritability estimated by models for tick count and hair coat.

\begin{tabular}{|c|c|c|c|c|}
\hline Model & $\sigma_{a}^{2}$ & $\sigma_{e}^{2}$ & $\sigma_{p}^{2}$ & Heritability \\
\hline \multicolumn{5}{|c|}{ - } \\
\hline M1 & $0.02 \pm 0.005$ & $0.12 \pm 0.004$ & $0.14 \pm 0.002$ & $0.14 \pm 0.037$ \\
\hline M2 & $0.04 \pm 0.007$ & $0.11 \pm 0.006$ & $0.15 \pm 0.002$ & $0.26 \pm 0.044$ \\
\hline M3 & $0.03 \pm 0.005$ & $0.12 \pm 0.005$ & $0.15 \pm 0.002$ & $0.18 \pm 0.038$ \\
\hline M4 & $0.02 \pm 0.005$ & $0.12 \pm 0.004$ & $0.14 \pm 0.002$ & $0.14 \pm 0.036$ \\
\hline \multicolumn{5}{|c|}{ 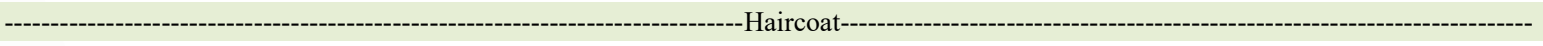 } \\
\hline M1 & $0.05 \pm 0.003$ & $0.16 \pm 0.002$ & $0.21 \pm 0.001$ & $0.22 \pm 0.014$ \\
\hline M2 & $0.06 \pm 0.003$ & $0.16 \pm 0.002$ & $0.22 \pm 0.001$ & $0.28 \pm 0.014$ \\
\hline M3 & $0.05 \pm 0.003$ & $0.16 \pm 0.002$ & $0.21 \pm 0.001$ & $0.26 \pm 0.014$ \\
\hline M4 & $0.05 \pm 0.003$ & $0.16 \pm 0.002$ & $0.21 \pm 0.001$ & $0.22 \pm 0.013$ \\
\hline
\end{tabular}

M1 = breed composition within the contemporary group; M2 = breed composition outside of the contemporary group; M3 = breed composition as covariable and M4 = two contemporary groups; the first comprised sex, management group, year and season of the count, and the second considered only the effects of latitude and breed composition. 
stable. Similar estimates were observed by AYRES, et al. (2014) for Hereford-Nelore crossed population, CARDOSO et al. (2015) and MOTA et al. (2016) for Braford and Hereford breeds. OLIVEIRA et al. (2012) estimated heritability equal to 0.42 for the Braford and Hereford breeds and justified their result to the use of the genomic relationship matrix. The high heritability was reported by OTTO et al. (2018) 0.54 for tick counting in Girolando animals in the dry season, the authors contextualize that the differences in heritability estimates can be explained by the different statistical models applied in each experiment.

The variance for hair coat presented the same behavior, the residual variances were close to 0.16 and the lowest genetic variance observed for M1 and M4 was 0.05 . The heritability estimated by M1 for hair coat was 0.22 , being lower than that the reported by PRAYAGA \& HENSHALL (2005) for genetic groups derived from British and Sanga breeds $(0.26)$ and by BARICHELLO et al. (2010) for Canchim breed (0.52). However, the heritability estimated in our study was higher than that mentioned by MORRIS et al. (2011) for hair length, according to REIMANN et al. (2018) hair length is the measure that most closely resembles the evaluation of hair coat scores. This indicated that the estimate is according to the estimates already reported in the literature.

The estimated genetic correlation between tick count and hair coat was -0.12 , a similar value $(-0.105)$ reported by PORTO-NETO et al. (2014) for Brahman animals, the same authors reported a genetic correlation of 0.065 for animals of a tropical composite. REIMANN et al. (2018) reported 0.29 for tick counts with hair coat at weaning and 0.26 at yearling, indicating that the most of the genes responsible for expression of each of these traits is different and that selection for one trait should promote little change in the other in this population.

The Spearman's rank correlations between the genetic values estimated by M1 and the genetic values estimated by M2, M3 and M4, for the top $10 \%$ best sires, were $0.53,0.52$ and 0.52 , respectively, for tick counts, and were 0.79, 0.92 and 0.92, respectively, for hair coat (Table 4). These moderate correlations suggested that the definition of fixed effects, as well as the way they are considered in the model, may alter the order of classification of sires, resulting in incorrect predictions of genetic values. When heterogeneous variances are ignored in statistical modeling, a larger proportion of animals in more variable environments tends to be classified at the upper end of the genetic value distribution (HILL, 1984; GIANOLA, 1986).

\section{CONCLUSION}

Higher tick count values occurred at lower latitudes and during spring. Therefore, control procedures should be adopted at this time of year. The most effective model to estimate genetic parameters was M1, which considers the genetic group within the contemporary group. Selection for genetically resistant animals promotes slow genetic progress. However, this is an effective alternative for reducing ticks infestation.

Table 4 - Spearman correlation between estimated breeding values obtained by different models, considering top $10 \%$ sires for tick count (above the diagonal) and hair coat (below the diagonal).

\begin{tabular}{llccc}
\hline & M1 & M2 & M3 & M4 \\
\hline M1 & & 0.53 & 0.52 & 0.52 \\
M2 & 0.79 & & 0.81 & 0.29 \\
M3 & 0.92 & 0.76 & 0.74 \\
\hline
\end{tabular}




\section{ACKNOWLEDGEMENTS}

The authors thanks CNPq for financial support, and was financed in part by the Coordenação de Aperfeiçoamento de Pessoal de Nível Superior (CAPES), Brasil - Finance code 001.

\section{BIOETHICS AND BIOSSECURITY COMMITTEE APPROVAL}

There is no need for approval by the institutional ethics committee due to the fact that the animal data are not of experimental origin and are provided by the company Gensys.

\section{DECLARATION OF CONFLICT OF INTEREST}

The authors declare no conflict of interest. The founding sponsors had no role in the design of the study; in the collection, analyses, or interpretation of data; in the writing of the manuscript, and in the decision to publish the results.

\section{AUTHORS' CONTRIBUTIONS}

GLF, AMP, MMO and FCBM conceived and designed analyses. FCBM and PRNR supervised and coordinated the work. VMR provided data and supervised. GLF, AMP, VTM and MMO performed statistical analysis. GLF, FCBM and MMO prepared the draft of the manuscript. All authors critically revised the manuscript and approved of the final version.

\section{REFERENCES}

ANDRADE, A. B. F. et al. Genetic and environmental aspects of the resistance of zebu cattle to the tick Boophilus microplus. Armidale, AU, In: World Congress on Genetics Applied to Livestock Production, 1998. p.339-342.

AYRES, D. R. et al. Linear and Poisson models for genetic evaluation of tick resistance in cross-bred Hereford $\mathrm{x}$ Nellore cattle. Journal of Animal Breeding and Genetics, 2013. v.130, n.6, p.417-424. Available from: <https://pubmed.ncbi.nlm.nih. gov/24236604/>. Accessed: Jul. 21, 2020. doi: 10.1111/jbg.12036.

AYRES, D. R. et al. Genetic parameters and investigation of genotype $\times$ environment interactions in Nellore $\times$ Hereford crossbred for resistance to cattle ticks in different regions of Brazil. Journal of Applied Genetics, 2014. v.56, n.1, p.107-113. Available from: $<$ https://link.springer.com/article/10.1007/s13353014-0238-5>. Accessed: Jul. 21, 2020. doi: 10.1007/s13353-014 0238-5.

BARICHELLO, F. et al. Heritability and correlations for weight, scrotal circumferenceand visual scores at weaning, in Canchim beef cattle Pesquisa Agropecuaria Brasileira, 2010. v.45, n.6, p.563570. Available from: $<$ https://www.scielo.br/scielo.php?script $=$ sci arttext\&pid=S0100-204X2010000600005>. Accessed: Jul. 21, 2020. doi: 10.1590/S0100-204X2010000600005.

BRUM, J.; et al., Seasonal fluctuation of Boophilus microplus (Canestrini, 1887) in the municipality of Pelotas, RS. Arquivo Brasileiro de Medicina Veterinária e Zootecnia, 1987. v.39, p.891-896.
BURROW, H. M. et al. Towards a new phenotype for tick resistance in beef and dairy cattle: A review. Animal Production Science, 2019. v.59, n.8, p.1401-1427. Available from: <https:// doi.org/10.1071/AN18487>. Accessed: Oct. 27, 2020. doi: 10.1071/AN18487.

CARDOSO, F. F. et al. Genomic prediction for tick resistance in Braford and Hereford cattle. Journal of Animal Science, 2015. v.93, p.2693-2705. Available from: <https://academic.oup.com/ jas/article-abstract/93/6/2693/4703464>. Accessed: Jul. 21, 2020. doi: $10.2527 /$ jas.2014-8832.

CARDOSO, V.; FRIES, L. A.; ALBUQUERQUE, L. G. De; Comparação de diferentes métodos de avaliação da resistência genética de bezerros $\mathrm{fl}$ angus x nelore desmamados ao carrapato. Jaboticabal, SP, In: III Simpósio Nacional de Melhoramento Animal, 2000. p.460-463.

COBuCI, J. A.; ABREU, U. G. P. De; TORRES, R. De A. Formação de Grupos Contemporâneos em Bovinos de Corte. Corumbá, MS. 2006. 26p. (Boletim Técnico, Documento 87).

FRAGA, A. B. et al. Genetic Analysis of the Infestation of Caracu Female Cattle Breed by Cattle Tick (Boophilus microplus). Revista Brasileira de Zootecnia, 2003. v.32, n.6 SUPPL.1, p.1578-1586. Available from: <https://www.scielo.br/scielo.php?pid=S151635982003000700006\&script $=$ sci_abstract\&tlng=pt $>$. Accessed: Jul. 21, 2020. doi: 10.1590/S1516-35982003000700006.

GASPARIN, G. et al. Mapping of quantitative trait loci controlling tick [Riphicephalus (Boophilus) microplus] resistance on bovine chromosomes 5, 7 and 14. Animal Genetics, 2007. v.38, n.5, p.453-459. Available from: <https://onlinelibrary.wiley.com/doi/ abs/10.1111/j.1365-2052.2007.01634.x>. Accessed: Jul. 21, 2020. doi: $10.1111 / \mathrm{j} .1365-2052.2007 .01634 . x$.

GEWEKE, J. Evaluating the Accuracy of Sampling-Based Approaches to the Calculation of Posterior Moments. In: BERNARDO, J.M.; BERGER, J.O.; DAWID, A.P.; SMITH, A.F.M. (Eds.), Bayesian Statistics. Oxford University Press: Oxford, 1992, v.4, p.1-31.

GIANOLA, D. On selection criteria and estimation of parameters when the variance is heterogeneous. Theoretical and Applied Genetics, 1986. v.72, n.5, p.671-677. Available from: <https:// link.springer.com/article/10.1007\%2FBF00289007>. Accessed: Jul. 21, 2020. doi: 10.1007/BF00289007.

GUGLIELMONE, A. A.; NAVA, S. Epidemiología y control de las garrapatas de los bovinos en la Argentina. In: NARI, A.; FIEL, C. (Org.). Enfermedades parasitarias con importancia clínica y productiva en rumiantes: fundamentos epidemiológicos para su diagnostico y control. Editorial ed. Buenos Aires, 2013, p. $441-456$.

HILL, W. G. On selection among groups with heterogeneous variance. Animal Production, 1984. v.39, n.3, p.473-477. Available from: <https://www.cambridge.org/core/journals/ animal-science/article/on-selection-among-groups-withheterogeneous-variance/4B1629187F260784C8D0D135262431 EF>. Accessed: Jul. 21, 2020. doi: 10.1017/S0003356100032220.

JONGEJAN, F.; UILENBERG, G. The global importance of ticks. Parasitology, 2004. v.129, p.3-14. Available from: $<$ https:// pubmed.ncbi.nlm.nih.gov/16472920/>. Accessed: Oct. 21, 2020. doi: 10.1016/j.vetpar.2006.01.010. 
JONSSON, N. N. The productivity effects of cattle tick (Boophilus microplus) infestation on cattle, with particular reference to Bos indicus cattle and their crosses. Veterinary Parasitology, 2006. v.137, n.1-2, p.1-10. Available from: <https://pubmed.ncbi.nlm. nih.gov/15938502/>. Accessed: Oct. 21, 2020. doi: 10.1017/ s0031182004005967.

LA FUENTE, J. DE et al. A ten-year review of commercial vaccine performance for control of tick infestations on cattle. Animal health research reviews / Conference of Research Workers in Animal Diseases, 2007. v.8, n.1, p.23-28. Available from: $<$ https://pubmed.ncbi.nlm.nih.gov/17692140/>. Accessed: Jul. 21, 2020. doi: $10.1017 / \mathrm{S} 1466252307001193$.

LEW-TABOR, A. E. .; RODRIGUEZ VALLE, M.. A review of reverse vaccinology approaches for the development of vaccines against ticks and tick borne diseases. Ticks and Tick-borne Diseases, 2016. v.7, n.6, p.1236-1237. Available from: <https:// pubmed.ncbi.nlm.nih.gov/26723274/>. Accessed: Jul. 21, 2020. doi: 10.1016/j.ttbdis.2015.12.012.

MENDES, M. C. et al. Resistance to cypermethrin, deltamethrin and chlorpyriphos in populations of Rhipicephalus (Boophilus) microplus (Acari: Ixodidae) from small farms of the State of São Paulo, Brazil. Veterinary Parasitology, 2011. v.178, n.3-4, p.383-388. Available from: <http://dx.doi.org/10.1016/j. vetpar.2011.01.006>. Accessed: Jul. 21, 2020. doi: 10.1016/j. vetpar.2011.01.006

MISZTAL, I. et al. Manual for BLUPF90 family of programs. university of Georgia, Athens, USA, 2015. p. 125. Available from: $<$ http://nce.ads.uga.edu/wiki/lib/exe/fetch.php?media=blupf90 all2.pdf $>$. Accessed: Jul. 21, 2020.

MORRIS, C. A.; AMYES, N. C.; HICKEY, S. M. Responses of prolactin and hair growth to selection for age at puberty in Angus cattle. Animal, 2011. v.5, n.2, p.198-201. Available from: <https:// pubmed.ncbi.nlm.nih.gov/22440764/>. Accessed: Jul. 21, 2020. doi: $10.1017 /$ S1751731110001825.

MOTA, R. R. etal. Genotype by environment interaction for tick resistance of Hereford and Braford beef cattle using reaction norm models. Genetics Selection Evolution, 2016. v.48, n.1, p.1-12. Available from: <https:// www.ncbi.nlm.nih.gov/pmc/articles/PMC5518165/>. Accessed: Jul. 21, 2020. doi: 10.1186/s12711-015-0178-5.

OLIVEIRA, M. M. D. et al. Seleção genômica para resistência a carrapatos em bovinos Braford e Hereford. João Pessoa, PB. In: IX Simpósio Brasileiro de Melhoramento Animal, 2012. p.20-22.

OTTO, P. I. et al. Genome-wide association studies for tick resistance in Bos taurus $\times$ Bos indicus crossbred cattle: A deeper look into this intricate mechanism. Journal of Dairy Science, 2018. v.101, n.12, p.11020-11032. Available from: $<$ https://www. sciencedirect.com/science/article/pii/S0022030218308592>. Accessed: Jul. 21, 2020. doi: 10.3168/jds.2017-14223.

PENNA, V. M. Boophilus microplus: a resistência genética do hospedeiro como forma de controle. Caderno Técnico Escola Veterinária UFMG. v.4, p.3-65, 1989.

PORTO-NETO, L. R. et al. The genetic architecture of climatic adaptation of tropical cattle. PLoS ONE, 2014. v.9, n.11, p.1-22. Available from: <https://journals.plos.org/plosone/ article?id=10.1371/journal.pone.0113284 $>$. Accessed: Jul. 21, 2020. doi: 10.1371/journal.pone.0113284.

PRAYAGA, K. C.; HENSHALL, J. M. Adaptability in tropical beef cattle: Genetic parameters of growth, adaptive and temperament traits in a crossbred population. Australian Journal of Experimental Agriculture, 2005. v.45, n.7-8, p.971-983. Available from: <https://www.publish.csiro.au/an/ea05045>. Accessed: Jul. 21, 2020. doi: 10.1071/ea05045.

REIMANN, F. A. et al. Genetic parameters and accuracy of traditional and genomic breeding values for eye pigmentation, hair coat and breed standard in Hereford and Braford cattle. Livestock Science, 2018. v.213, n.February, p.44-50. Available from: $<$ https://doi.org/10.1016/j.livsci.2018.04.007>. Accessed: Jul. 21, 2020. doi: 10.1016/j.livsci.2018.04.007.

RODRÍGUEZ-MOLANO, C.-E.; et al., Background on the control of the cattle tick R. (B.) microplus and the use of coumarin substances as an alternative. Pharmacy \& Pharmacology International Journal, 2020. v.8, n.4, p.215-232. Available from: $\quad<$ https://medcraveonline.com/PPIJ/PPIJ-08-00299.pdf $>$. Accessed: Oct. 28, 2020. doi: 10.15406/ppij.2020.08.00299.

SAS. Institute Inc. 2013. Base SAS ${ }^{\circledR}$ 9.3 Procedures Guide. Cary, NC: SAS Institute Inc.

SCHLÖGL, K. S. et al. Spatiotemporal cluster and incidence analysis of cattle mortality caused by bovine babesiosis in Styria, Austria, between 1998 and 2016. Parasitology Research, 2020. v.119, n.3, p.1117-1123. Available from: <https://www.ncbi.nlm. nih.gov/pmc/articles/PMC7075847/>. Accessed: Jul. 21, 2020. doi: $10.1007 / \mathrm{s} 00436-020-06604-8$.

SILVA, A. M. DA et al. Artificial infestation of Boophilus microplus in beef cattle heifers of four genetic groups. Genetics and Molecular Biology, 2007. v.30, n.4, p.1150-1155. Available from: $\quad<$ https://www.scielo.br/scielo.php?script=sci_arttext\&pi $\mathrm{d}=\mathrm{S} 1415-47572007000600020>$. Accessed: Jul. 21, 2020. doi: 10.1590/S1415-47572007000600020.

SILVA, D. A. DA et al. Contemporary groups in the genetic evaluation of Nellore cattle using Bayesian inference. Pesquisa Agropecuaria Brasileira, 2017. v.52, n.8, p.643-651. Available from: <https://www.scielo.br/scielo.php?script=sci arttext\&pid=S0100-204X2017000800643>. Accessed: Jul. 21, 2020. doi: 10.1590/s0100-204×2017000800010.

SMITH, B. J. boa: An R package for MCMC output convergence assessment and posterior inference. Journal of Statistical Software, 2007. v.21, n.11, p.1-37. Available from: $<$ https://www. jstatsoft.org/article/view/v021i11>. Accessed: Jul. 21, 2020. doi: 10.18637/jss.v021.i11.

SPIEGELHALTER, D. J. et al. Bayesian Deviance with discussion JRSSB 2002. Applied Statistics, 2002. v.46, n.2, p.261-304. Available from: $\quad<$ https://rss.onlinelibrary.wiley.com/doi/pdf/10.1111/14679868.00353>. Accessed: Jul. 21, 2020. doi: 10.1111/1467-9868.00353.

VERÍSSIMO, C. J. et al. Cattle herd shearing can help to control Rhipicephalus microplus ticks. Experimental and Applied Acarology, 2019. v.79, n.1, p.99-106. Available from: <https:// link.springer.com/content/pdf/10.1007/s10493-019-00413-0.pdf $>$. Accessed: Jul. 21, 2020. doi: 10.1007/s10493-019-00413-0. 